TINJAUAN PUSTAKA

\title{
Hubungan Volume Cairan dengan Cardiac Output dan Venous Return pada Pasien Kritis
}

\section{Relationship of Volume to Cardiac Output and Venous Return in Critical Illness}

Rr. Listiana Dewi Sartika ${ }^{\varpi *}$, Erwin Pradian ${ }^{* *}$, Nurita Dian ${ }^{* *}$, Reza W Sudjud**, Ricky Aditya $^{* *}$

*SMF Anestesiologi dan Terapi Intensif/ RSUD dr. Loekmonohadi Kudus, Kudus, Indonesia ** Departemen Anestesiologi dan Terapi Intensif, Fakultas Kedokteran, Universitas Padjadjaran/ Rumah Sakit Hasan Sadikin Bandung, Bandung, Indonesia

${ }^{\square}$ Korespondensi: listianadewisartika@gmail.com

\begin{abstract}
Volume infusion is one of the commonest clinical interventions in critically ill patients. Science of body fluids used to focus more on the physiology of the left heart. Cardiac output, initially better known as left heart function where cardiac output is determined by the amount of blood pumped from the left ventricle in a minute (stroke volume) and heart rate. However, it turns out that understanding cardiovascular physiology is not that simple. According to Starling, the heart will only pump blood that is flow in to the right heart. Thus, the amount of blood entering the right heart must be the same as the amount of blood pumped by the left heart, both of these are called cardiac output. This was later investigated by Guyton. Guyton tried to view cardiac output as blood entering the right heart (venous return). There are many factors that determine the return of fluid to the right heart. Gradient pressure factor between mean systemic filling pressure (MSFP) and right atrial pressure, and also venous resistance are determinant factors in venous return function. Guyton also looked for a relationship between heart function and venous return. The understanding of cardiac output both as a function of the heart and as a function of venous return can explain many things related to cardiovascular dysfunction and extra cardiac disorders in critically ill patients such as in shock conditions. So, it is important to understand the relationship of volume to cardiac output and venous return.
\end{abstract}

Keywords: cardiac output; capacitance; compliance; mean systemic filling pressure; stressed volume; venous return 


\begin{abstract}
ABSTRAK
Pemberian cairan merupakan salah satu intervensi medis yang sering dilakukan pada pasien kritis di intensif care unit (ICU). Perkembangan ilmu mengenai cairan tubuh dulu lebih menitikberatkan pada fisiologi jantung kiri. Cardiac output, pada mulanya lebih dikenal sebagai fungsi jantung kiri dimana cardiac output ditentukan oleh jumlah darah yang dipompa dari ventrikel kiri dalam semenit (stroke volume) dan heart rate. Namun demikian, ternyata pemahaman fisiologi kardiovaskular tidak sesederhana itu. Menurut Starling, jantung hanya akan memompa darah yang masuk ke dalam jantung kanan. Dengan demikian, jumlah darah yang masuk ke jantung kanan harus sama dengan jumlah darah yang dipompa oleh jantung kiri, dimana keduanya adalah cardiac output. Ini kemudian diteliti lagi oleh Guyton. Guyton mencoba memandang cardiac output sebagai darah yang masuk ke jantung kanan (venous return). Terdapat banyak faktor yang menentukan kembalinya cairan ke jantung kanan. Faktor perbedaan tekanan antara mean systemic filling pressure (MSFP) dengan tekanan atrium kanan, serta faktor resistensi vena merupakan faktor penentu dalam fungsi venous return. Guyton juga mencari hubungan antara fungsi jantung dengan fungsi venous return. Pemahaman cardiac output secara utuh baik sebagai fungsi jantung dan sebagai venous return ini dapat menjelaskan banyak hal yang berhubungan dengan disfungsi kardiovaskular maupun gangguan ekstra kardiak pada pasien kritis dengan kondisi syok. Oleh karena itu, sangat penting bagi klinisi untuk memahami hubungan antara cairan tubuh dengan cardiac output dan venous return.
\end{abstract}

Kata Kunci: cardiac output; capacitance; compliance; mean systemic filling pressure; stressed volume; venous return

\section{PENDAHULUAN}

Pemberian cairan pada pasien kritis di intensive care unit (ICU) dan pasien fase perioperatif sangat tergantung pada keputusan tenaga medis dan paramedis, baik dalam jumlah, jenis dan saat pemberiannya. ${ }^{1}$ Pemberian cairan ini akan berpengaruh terhadap tubuh pasien, terlebih pada pasien kritis dengan perubahan status cairan yang disebabkan karena penyakit tertentu, penyakit komorbid, syok, anestesi atau terapi diuretik. $^{2}$ Pada pasien kritis seringkali didapatkan kondisi penurunan fungsi autoregulasi hormonal serta adanya disfungsi miokard. Disisi lain, pemberian cairan yang berlebihan dapat menimbulkan edema paru, gagal jantung, infeksi, pemanjangan lama rawat dan meningkatkan kematian. Oleh sebab itu perlu pengetahuan klinisi yang baik tentang fisiologi dan optimalisasi status volume pasien, agar dapat memaksimalkan delivery oksigen ke organ-organ vital.

\section{Sejarah fisiologi cairan Frank- Starling dan Guyton}

Starling dan Bayliss pada tahun 1894 menyatakan bahwa sirkulasi vena sangat penting namun perannya dapat diabaikan dalam fisiologi sirkulasi. ${ }^{3}$ Pada tahun 1914, Starling melakukan eksperimen untuk menilai cardiac output, dikenal dengan istilah Law of Heart. Dilakukan percobaan torakotomi pada anjing yang dianestesi dengan positive pressure ventilation dimana bagian distal aorta, vena cava inferior dan cabang arcus aorta diligasi. Arcus aorta dikanulasi dan dihubungkan dengan sirkuit 
ekstrakorporeal. Dari eksperimen ini Frank-Starling menemukan bahwa "jantung hanya dapat mengeluarkan volume darah sesuai dengan yang diterimanya dari atrium kanan". Disini mulai dikenal sirkulasi darah sebagai sirkulasi tertutup, bahwa jumlah darah yang keluar dari jantung harus sama dengan darah yang masuk ke jantung. Kemudian juga ditemukan bahwa penambahan jumlah cairan yang masuk ke jantung, pada awalnya akan menaikkan tekanan pada atrium kanan, sampai batas tertentu. Bila melebihi batas ini, maka jantung akan fatique (istilah dari Starling). Kurva FrankStarling ini ditunjukkan oleh Gambar 1 dimana tekanan pada atrium kanan akan bertambah oleh penambahan volume, yang disebut preload dependen, sedangkan bagian dari tekanan atrium kanan yang tidak bertambah walaupun diberikan penambahan volume disebut preload independen. ${ }^{4}$

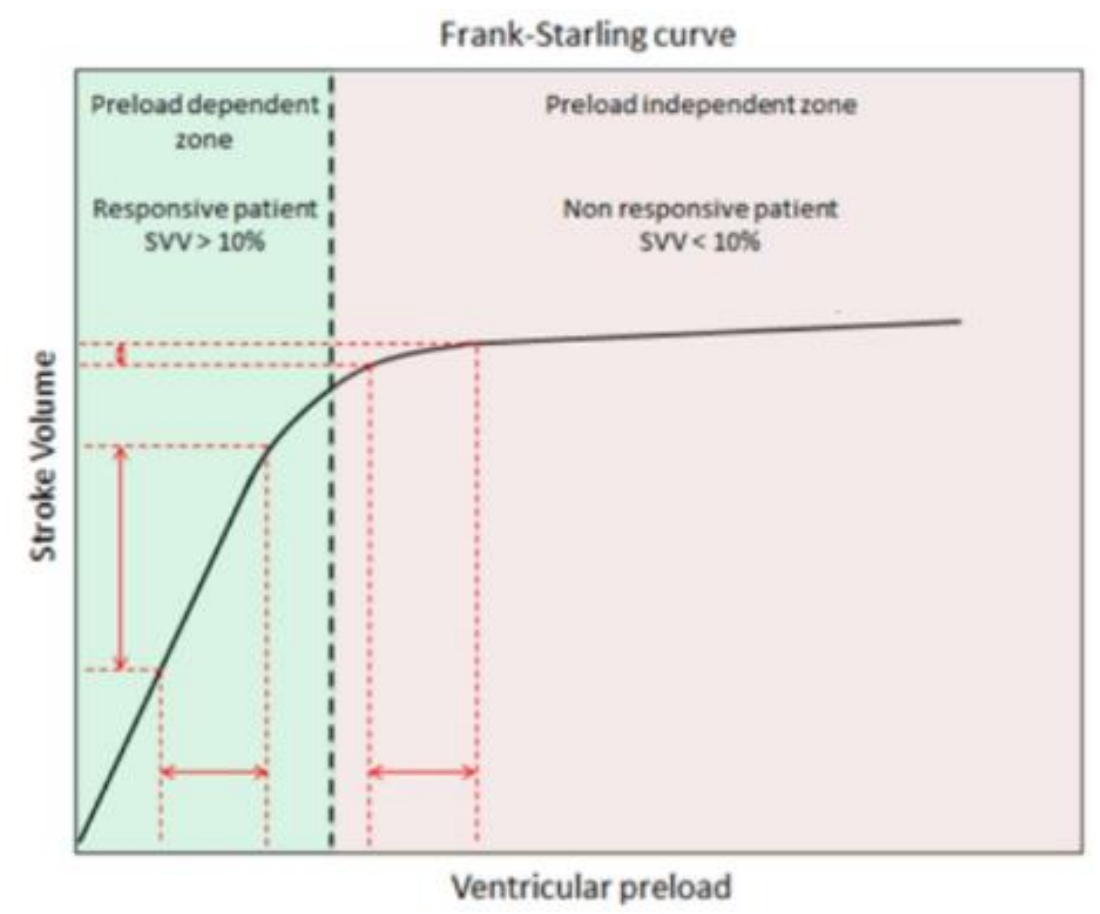

Gambar 1. Kurva Frank-Starling ${ }^{5}$

Braunwald pada tahun 1960 menemukan bahwa nilai stroke volume akan bervariasi sesuai tekanan pada atrium kanan. Braunwald juga menyatakan bahwa fase inspirasi dalam pada proses pernapasan manusia akan menaikkan tekanan intratoraks yang berakibat penurunan pada tekanan atrium kanan. Penurunan tekanan atrium kanan akan meningkatkan pengisian ventrikuler dan meningkatkan stroke volume. ${ }^{4}$
Pada tahun 1955 Arthur Guyton, seorang dokter ahli fisiologi berkebangsaan Amerika, tertarik untuk lebih mendalami hasil penelitian Starling, terutama mengenai pernyataan bahwa jantung hanya dapat mengeluarkan apa yang kembali pada jantung. Guyton mendalami cardiac output dari sisi venous return dan mendefinisikan venous return sebagai aliran yang menuju atrium kanan, dimana aliran ini sangat tergantung pada perbedaan tekanan (pressure gradien) antara central venous pressure (CVP) dan mean 
systemic filling pressure (MSFP).

Cardiac output bersifat dependen terhadap venous return dan bahwa venous return dependen terhadap tekanan sebelumnya (upstream) dalam sistem sirkulasi yang didefinisikan oleh Starling sebagai mean systemic pressure. Guyton juga berusaha mencari hubungan antara venous return dengan kurva jantung dari Starling., 5

MSFP merupakan tekanan yang berada pada seluruh sirkulasi sistemik, saat tidak ada aliran dan volume darah tersebar merata pada sirkulasi dengan tekanan yang sama. Pada percobaan awalnya, Guyton menghentikan aliran darah dengan menggunakan defibrilasi jantung. Tekanan yang diukur saat tidak ada aliran darah ini disebut sebagai (MSFP). ${ }^{6}$

Pada artikel ini, akan dibahas lebih lanjut mengenai fisiologi kardiovaskular menurut Guyton dan dikorelasikan dengan kurva fungsi jantung dari FrankStarling serta hubungannya dengan volume tubuh pasien. Artikel ini juga akan membahas beberapa kondisi pada pasien kritis yang berpengaruh terhadap venous return, cardiac output dan volume tubuh.

\section{HUBUNGAN VOLUME CAIRAN DAN VENOUS RETURN DENGAN CARDIAC OUTPUT}

Untuk memahami lebih jauh mengenai fisiologi aliran kardiovaskular, perlu dimengerti terlebih dahulu istilah-istilah yang berhubungan dengan aliran darah, pembuluh darah dan jantung. Istilahistilah tersebut akan diulas singkat dibawah ini.

\section{Cardiac output}

Cardiac output merupakan jumlah darah yang dipompa oleh jantung ke aorta setiap menit. Cardiac output mencerminkan jumlah darah ini mengalir ke seluruh sirkulasi darah. Nilai cardiac output dipengaruhi oleh faktor metabolisme basal latihan, umur dan ukuran tubuh. Untuk laki-laki dewasa muda normalnya 5,6 L/menit, dan untuk wanita dewasa muda 4,9 L/menit. ${ }^{7}$

\section{Venous return}

Venous return adalah jumlah darah yang mengalir melalui vena menuju atrium kanan setiap menit. Jumlah antara cardiac output dengan venous return harus sama satu dengan yang lainnya. Venous return nilainya dipengaruhi oleh perbedaan tekanan antara MSFP dengan tekanan pada atrium kanan. Saat tidak terdapat perbedaan tekanan antara keduanya, maka tidak terjadi aliran, atau venous return sama dengan nol. ${ }^{7}$

\section{Constant volume}

Sirkulasi darah manusia merupakan sirkulasi tertutup yang volumenya konstan pada kondisi normal. Volume ini meregangkan dinding elastis dari struktur pembuluh darah dan menghasilkan daya recoil elastis yang tetap ada meskipun tidak ada aliran. Daya ini juga merupakan faktor penting yang menentukan aliran darah. ${ }^{8}$

\section{Compliance}

Compliance merupakan pengukuran distensibilitas suatu struktur sferis yang ditentukan oleh perubahan pada volume yang mempengaruhi perubahan pressure. Contoh sederhananya adalah pengembangan balon dengan volume tertentu dan kemudian diukur perubahan pressure sepanjang dinding. Arti penting dari compliance yaitu bahwa gaya recoil elastic yang dihasilkan oleh peregangan dinding pembuluh darah akan menghasilkan gaya potensial yang mampu mengalirkan darah saat tekanan 
downstream lebih rendah. Selain itu, compliance juga memungkinkan aliran berdenyut melalui sirkuit tertutup. Saat kontraksi jantung menghasilkan gelombang aliran yang bergerak sepanjang pembuluh darah, maka dinding pembuluh darah harus dapat meregang sehingga mampu menangkap dan meneruskan gelombang aliran darah dari jantung. Tekanan yang dihasilkan dari peregangan dinding pembuluh darah dapat menggerakkan volume darah menuju tempat berikutnya dengan hanya menggunakan tekanan yang rendah. ${ }^{9}$

Compliance dari vena dan venula nilainya 40 kali lebih besar daripada arteri. Compliance dari arteri dan vena pada sirkulasi pulmonal hanya sekitar
1/7 dari sirkulasi sistemik. Total compliance dari vena dan venula mencapai $70 \%$ dari total volume darah. Arteri hanya memiliki compliance $18 \%$ dari total volume darah. $^{9}$

Vena merupakan tempat penyimpanan (reservoir) yang ideal dalam sistem pembuluh darah, ini disebabkan karena vena memiliki compliance yang tinggi. Tempat penyimpanan terbanyak terdapat pada sistem splaknik dimana tersimpan 20-30\% dari total volume darah. Hal ini menyebabkan perubahan besar pada volume darah tidak berhubungan langsung dengan perubahan signifikan pada tekanan transmural vena. ${ }^{8}$

Tabel 1. Distribusi darah pada sistem sirkulasi ${ }^{10}$

\begin{tabular}{lc}
\hline Struktur & Persentase dari total volume darah \\
\hline Sistem vena sistemik & 64 \\
Sistem arteri sistemik & 13 \\
Kapiler & 7 \\
Sirkuit Pulmonal & 9 \\
Jantung & 7 \\
\hline
\end{tabular}

\section{Volume darah}

Volume darah dapat dibedakan menjadi 2 macam yaitu: ${ }^{9}$

1. Stressed volume yaitu volume darah yang meregangkan pembuluh darah $(30 \%$ dari total volume darah)

2. Unstressed volume, yaitu volume darah yang diperlukan untuk mengisi pembuluh darah tanpa meregangkan pembuluh darah (70\% dari total volume darah)

Manusia dengan total volume darah 5,5 liter hanya terdiri dari 1,3-1,4 liter stressed volume sedangkan sisanya adalah unstressed volume. Keseluruhan dari stressed volume dan unstressed volume ini membentuk capacitance, dimana capacitance merupakan total volume yang dapat diberikan pada tekanan tertentu. ${ }^{8,9}$

Capacitance dipengaruhi oleh kontraksi atau relaksasi dari otot pembuluh darah. Capacitance akan menurun saat otot pembuluh darah vena dan venula memendek. Hal ini menyebabkan perubahan unstressed volume menjadi stressed volume, sehingga tekanan volume total meningkat. Pada laki-laki berat badan $70 \mathrm{~kg}$, aktivasi simpatis ekstrem dapat merubah $18 \mathrm{ml} / \mathrm{kg}$ unstressed volume menjadi stressed volume, sedangkan aktivasi simpatis moderat merubah $10 \mathrm{ml} / \mathrm{kg}$ unstressed volume menjadi stressed volume. ${ }^{8,9}$ 
Mean circulatory filling pressure (MCFP) dan mean systemic filling pressure (MSFP)

MSFP merupakan tekanan pada dinding pembuluh darah sistemik saat pembuluh darah terisi volume darah normal namun tidak terdapat aliran. Tekanan tersebut sama di seluruh bagian pembuluh darah. Namun, tekanan ini bukanlah mean circulatory filling pressure (MCFP) karena hanya menampung tekanan dari pembuluh darah sistemik saja dan tidak meliputi tekanan dari pembuluh darah pulmonal. MCFP sendiri merupakan penjumlahan dari MSFP dengan tekanan pulmonal. Oleh karena tekanan darah pulmonal nilainya sangat kecil, dan hanya 1/7 dari nilai tekanan MSFP, maka seringkali MSFP dianggap sama dengan MCFP. ${ }^{6,11}$

\section{Pengukuran MSFP}

MSFP dapat diestimasi dengan menggunakan prinsip bahwa MSFP merupakan tekanan rata-rata pada sistem pembuluh darah saat tidak ada aliran (no flow). Berbagai penelitian berusaha membuat kondisi "no flow" tersebut, kemudian mengukur tekanannya. Ditemukan 3 cara pengukuran MSFP yaitu: $^{12}$

\section{Inspiratory hold maneuver}

MSFP hold prinsipnya dengan
menggunakan persamaan
VR=MSFP-CVP/Rv. Apabila CVP
dinaikkan dengan melakukan
maneuver end-inspiratory hold serial,
maka saat didapatkan kondisi "no
flow" akan dapat diukur MSFP,
karena MSFP merupakan tekanan
saat tidak ada aliran.

Pasien disedasi, dikontrol pernapasannya dengan ventilasi mekanis, dilakukan pengukuran $\mathrm{CO}$ secara invasif. Inspirasi ditahan pada ventilator plateu pressure (Pvent) $5,15,25$ dan 35 cmH2O secara incremental, kemudian $\mathrm{CO}$ diukur pada 3 detik terakhir dalam 12 detik inspiratory hold. Dari penelitian ini ditemukan bahwa setelah 7-10 detik akan tercapai kondisi steady state dimana $\mathrm{VR}=\mathrm{CO}$. Dengan memplot nilai CVP dengan $\mathrm{CO}$, maka akan didapatkan kurva VR dan pressure pada zero flow yang dikenal sebagai MSFP. 12 Dengan metode ini, diperoleh nilai MSFP antara 19-33 $\mathrm{mmHg}$ dengan standar deviasi yang lebar. ${ }^{12}$

\section{MSFP arm}

MSFP arm menganut prinsip bahwa MSFP akan sama pada kompartemen pembuluh darah yang berbeda, meskipun mungkin masing-masing kompartemen memiliki stressed volume dan unstressed volume yang berbeda-beda. ${ }^{12}$

Cara pengukuran dengan metode ini dengan menggunakan rapid cuff inflator (dalam 0,3 detik) atau pneumatic tourniquet (dalam 1,4 detik) yang dikembangkan pada lengan atas sampai $50 \mathrm{mmHg}$ diatas tekanan darah sistolik. Dilakukan pengukuran pada tekanan arteri melalui kateter arteri radialis dan pengukuran tekanan vena dengan kanulasi vena perifer di lengan bawah. Ketika tekanan arteri dan tekanan vena ini didapatkan nilai yang sama, maka didapatkan nilai MSFP. Metode ini didapatkan MSFP berkisar antara 16-24 mmHg. ${ }^{12}$

\section{MSFP analogue}

Berdasar rumus Guyton $\mathrm{CO}=\mathrm{VR}=\mathrm{MSFP}-\mathrm{CVP} / \mathrm{Rv}$ didapatkan persamaan model matematika: 


\section{MSFP analogue $=$ axCVP+bxMAP $+c x C O$}

Dalam formula ini, a dan $b$ adalah konstanta tanpa dimensi $(a+b=1)$. Asumsi compliance veno-arterial adalah 24:1 maka $a=0,96$ dan $b=0,04$ c menunjukkan resistensi arteriovenous dan tergantung pada umur, tinggi badan dan berat badan. Dengan model ini, didapatkan baseline ratarata MSFP 14-18 mmHg. Pengukuran dengan cara ini menggunakan pengukuran berdasar CVP, MAP dan CO. Dimana CVP bervariasi tergantung ventilasi. Biasanya yang dipakai adalah end-expiratory CVP. ${ }^{12}$

\section{Hubungan venous return dengan MSFP dan CVP}

Postulat Guyton yang menyatakan bahwa cardiac output adalah sama dengan venous return, bila dikembalikan pada persamaan Hagen-Poisulle, maka akan didapatkan bahwa: ${ }^{9}$

$$
\mathrm{CO}=\mathrm{VR}=\frac{\mathrm{MSFP}-\mathrm{CVP}}{\mathrm{RV}}
$$

Dimana:

$\mathrm{CO} \quad$ : Cardiac output

VR :Venous return, dalam persamaan Guyton, VR= Cardiac output

MSFP : Mean systemic filling pressure

CVP : Central venous pressure

Rv : Resistensi vena

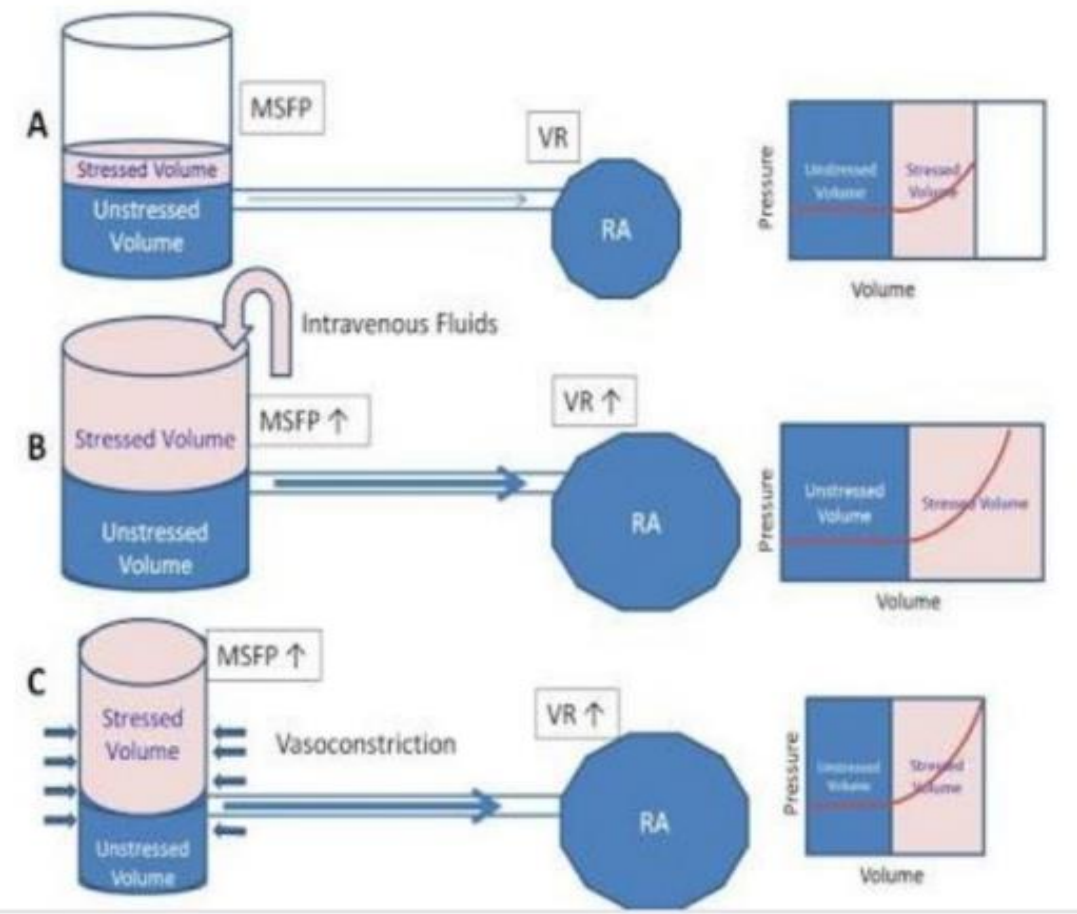

Gambar 2. Perubahan pada venous return. A. stressed volume meregangkan pembuluh darah dan mempengaruhi venous return (VR), sedangkan unstressed volume tidak meregangkan pembuluh darah. B. Pemberian cairan dapat meningkatkan MSFP dan VR. C. Perubahan unstressed volume menjadi stressed volume dengan aktivasi simpatis akan menambah jumlah stressed volume sehingga MSFP dan VR meningkat. ${ }^{9}$ 
MSFP dan stressed volume berperan penting dalam regulasi hemodinamik karena menentukan perbedaan tekanan (gradien pressure) dengan CVP untuk mendapatkan cardiac output normal. Cardiac output harus sama dengan venous return, artinya jumlah darah yang keluar dari left ventrikel (cardiac output) harus selalu sama dengan jumlah darah yang diterima oleh jantung kanan (venous return), dimana yang menentukan VR adalah perbedaan tekanan antara MSFP-CVP. Faktorfaktor yang dapat menurunkan gradien pressure MSFP-CVP yaitu penurunan MSFP atau peningkatan CVP. Jika gradien pressure menurun, venous return turun dan secara otomatis cardiac output turun. Tubuh akan selalu menjaga agar gradien pressure MSFP-CVP berkisar $8 \mathrm{mmHg}$. 9,13

Hubungan antara MSFP dengan stressed volume dinyatakan dalam persamaan: ${ }^{7}$

MSFP $=\frac{\partial}{\mathrm{Cv}}$

Dimana:

d : stressed volume

$\mathrm{Cv}$ : compliance

\section{Resistensi}

Resistensi merupakan kehilangan energi yang disebabkan oleh gaya gesekan. Resistensi tidak dapat diukur secara langsung tetapi dapat dihitung dengan melihat perbedaan antara tekanan saat masuk dikurangi tekanan saat keluar dari pembuluh darah, dibagi dengan aliran darah yang terjadi. ${ }^{7,9}$

Pada kondisi normal, darah akan mengalir melalui satu tempat dengan compliance tertentu menuju tempat lain dengan compliance yang berbeda secara simultan. Oleh sebab itu, resistensi tiap regio berbeda-beda tergantung volume dan compliance dari masing-masing regio. ${ }^{7,9}$

Resistensi bergantung dari tiga faktor, yaitu viskositas darah, panjang pembuluh darah dan jari-jari pembuluh darah.

Menurut persamaan Hagen-Poiseulle: ${ }^{11}$

$\mathrm{R}=\frac{8 \mathrm{n} 1}{\Pi \mathrm{r}^{4}}$

Dimana:

$\mathrm{R}=$ resistensi

$\underline{\eta}=$ viskositas darah

$1=$ panjang pembuluh

$\mathrm{r}=$ jari-jari pembuluh darah

Viskositas darah meningkat karena darah lebih hemokonsentrasi, dan berkurang bila darah lebih encer. Semakin besar viskositas darah, semakin besar resistensi. Sementara semakin panjang pembuluh akan meningkatkan resistensi, hal ini dapat dipahami karena semakin panjang pembuluh akan semakin besar gesekan dengan pembuluh darah. ${ }^{11}$

Regulasi utama resistensi pembuluh darah dalam tubuh adalah regulasi jarijari pembuluh. Resistensi berbanding terbalik dengan jari-jari pembuluh. Semakin besar jari-jari maka akan semakin kecil resistensinya demikian pula sebaliknya. ${ }^{9,11}$

\section{Model bath tube untuk persamaan venous return Guyton}

Untuk mempermudah membayangkan mekanisme venous return, Guyton membuat suatu model bak mandi (bath tube) yang menggambarkan hubungan antara stressed volume, unstressed volume, tekanan atrium kanan dan venous return. 


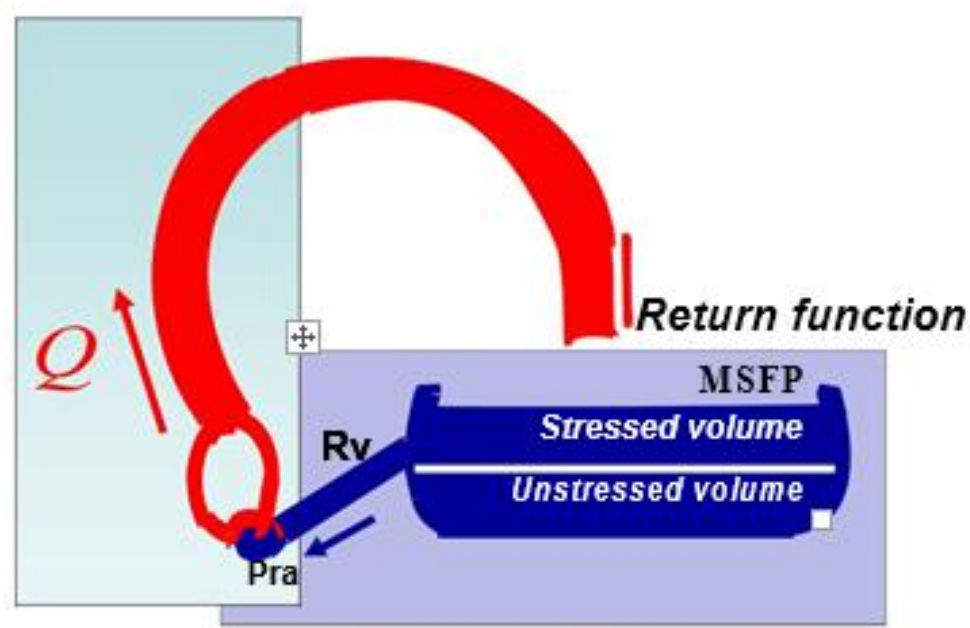

Gambar 3. Model bath tube untuk cardiac output. Cardiac output ditentukan oleh fungsi cardiac dan fungsi venous return. Q: Cardiac output, Pra: tekanan atrium kanan; $\mathrm{Rv}$; resistensi vena; MSFP: mean systemic filling pressure. ${ }^{9}$

Perubahan cardiac output dalam beberapa kondisi

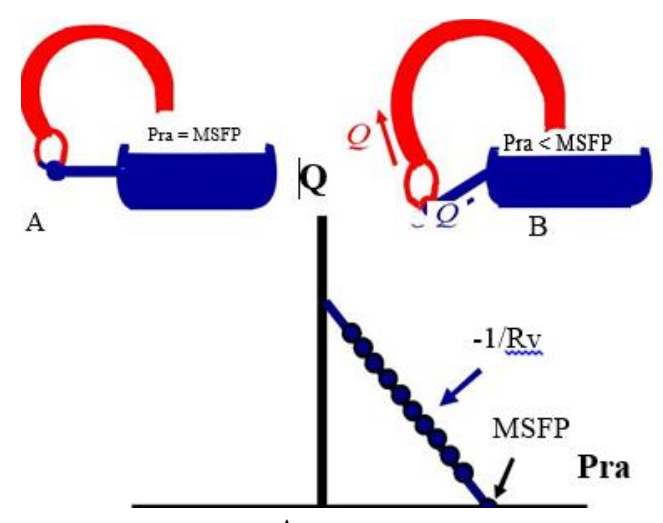

A

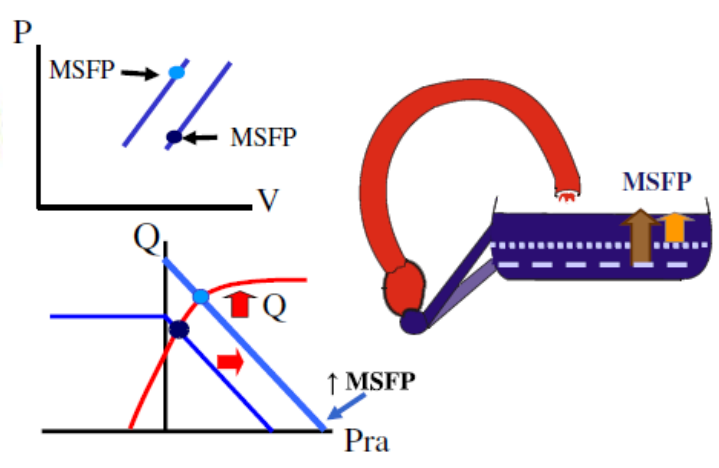

B

Gambar 4. A. Perubahan cardiac output, ketika tekanan atrium kanan (Pra) $=$ MSFP maka tidak akan terjadi aliran. B. Perubahan pada cardiac output dan venous return karena penambahan capacitance. ${ }^{7}$

Pada Gambar 4. A menunjukkan perubahan cardiac output akibat peningkatan tekanan atrium kanan (Pra). Pada saat tekanan atrium kanan sama dengan tekanan MSFP, maka tidak terjadi perbedaan tekanan, ini disebabkan karena MSFP-CVP $=0$. Tidak adanya perbedaan tekanan ini akan menyebabkan tidak terjadinya venous return.

Gambar 4. B menunjukkan bahwa penambahan capacitance (stressed volume dan unstressed volume) akan meningkatkan MSFP, dengan kata lain menurunkan mulut bath tube sehingga menambah aliran menuju jantung, karena terjadi penambahan stressed volume (gambar kanan). Secara grafik terjadi pergeseran ke kiri pada kurva volume-pressure (gambar kiri atas). Ini akan menggeser kurva VR ke kanan dan menambah cardiac output melalui mekanisme Starling (gambar kiri bawah). Efek ini identik dengan penambahan volume untuk menambah stressed volume. ${ }^{9}$ 


\section{Hubungan antara fungsi cardiac dengan venous return}

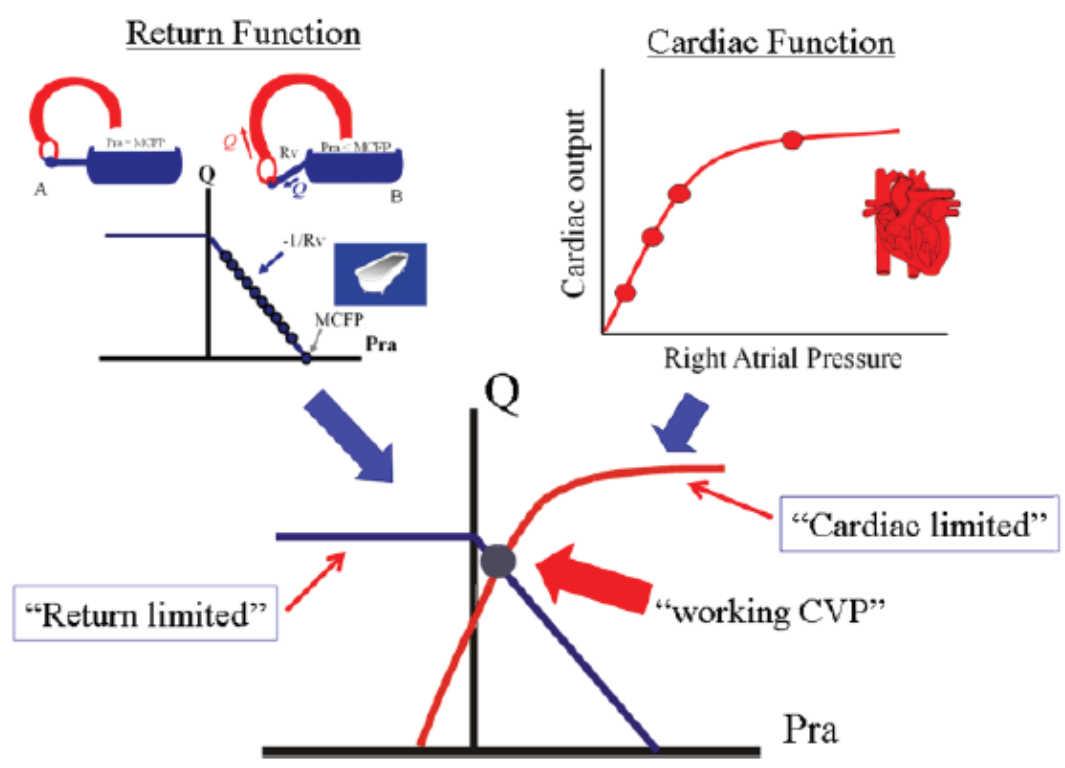

Gambar 5. Hubungan antara fungsi venous return dengan fungsi cardiac $^{5}$

Gambar 5 memperlihatkan kurva return function (kiri atas) dan kurva cardiac function (kanan atas), sumbu $\mathrm{X}$ dan sumbu Y kedua kurva sama, sehingga kedua kurva tersebut dapat dihimpitkan. Hasilnya ditunjukkan pada Gambar 5 (bawah), ditampilkan hubungan antara fungsi cardiac dengan venous return, dimana persinggungan antara kurva fungsi jantung Straling dengan kurva venous return Guyton merupakan working $C V P$ atau tekanan atrium kanan yang bekerja.

\section{Pembatasan fungsi venous return}

Pada grafik terlihat bahwa penurunan CVP sampai nilai dibawah nol tidak akan menaikkan cardiac output (Q), karena ketika tekanan di dalam pembuluh darah besar lebih kecil dari tekanan di sekitarnya (yaitu nol saat bernapas pada tekanan atmosfer) maka pembuluh darah besar akan kolaps dan aliran terhenti. Nilai VR maksimal tergantung pada
MSFP dan Rv, fungsi jantung tidak dapat membuat aliran melebihi nilai tersebut. ${ }^{5,9}$

\section{Pembatasan fungsi cardiac}

Cardiac function juga memiliki batasan, yang disebabkan karena restrain oleh pericardium dan cytoskeleton jantung. Ketika pengisian cardiac terbatas, maka penambahan tekanan pengisian diastolik tidak dapat menambah stroke volume, karena tidak ada penambahan end diastolic volume sehingga tidak ada penambahan panjang sarkomer jantung. ${ }^{9,11}$

Pada fungsi cardiac filling yang terbatas, maka cardiac output meningkat hanya dengan penambahan heart rate atau kontraktilitas, atau dengan menurunkan afterload. Ketika terjadi limitasi cardiac filling, maka cardiac output akan independen terhadap perubahan venous return. ${ }^{9}$ 


\section{Venous return dan cardiac output pada pasien kritis}

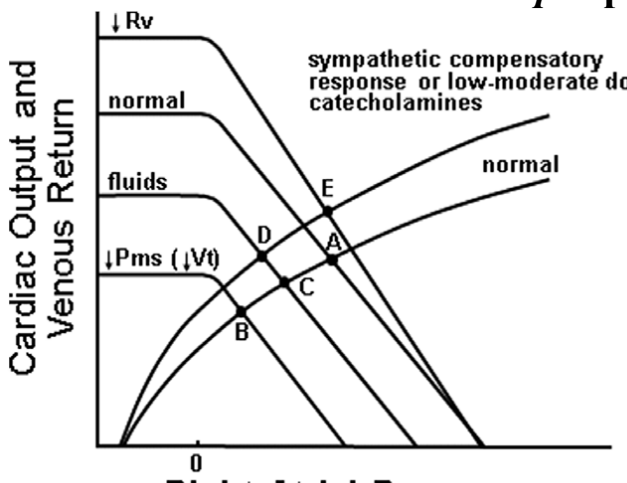

Right Atrial Pressure

A

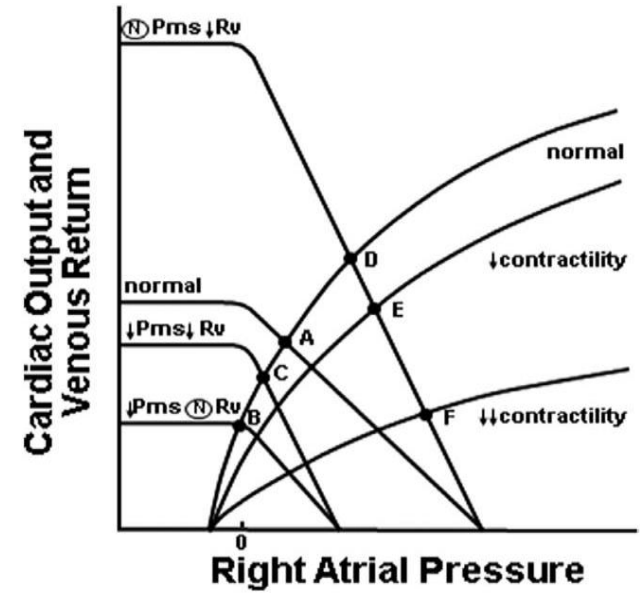

C

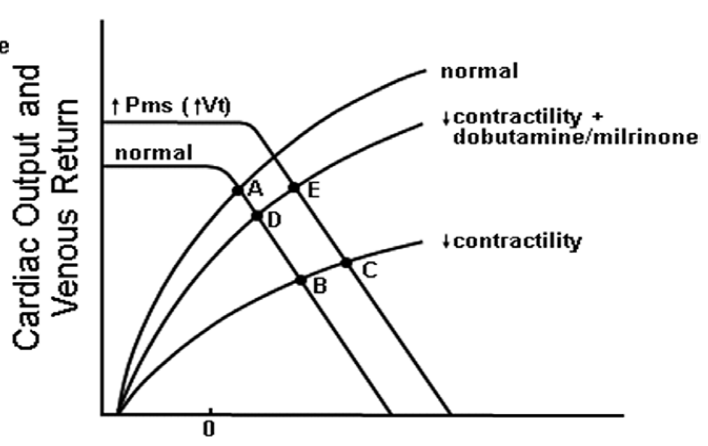

Right Atrial Pressure

B

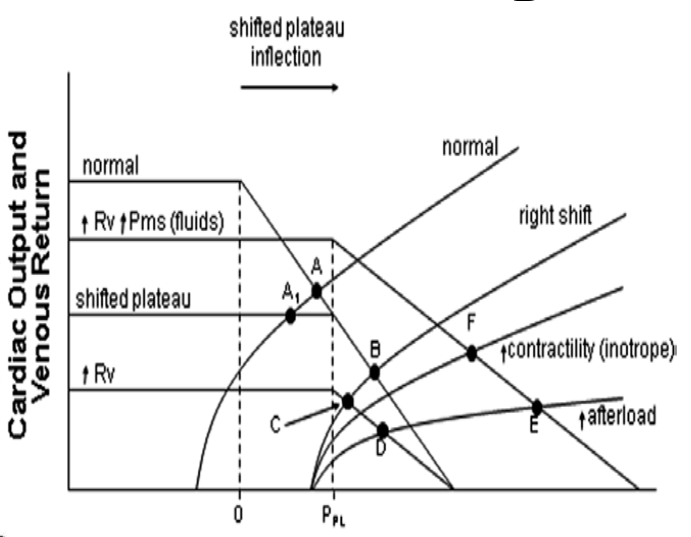

Right Atrial Pressure

Gambar 6. Perubahan venous return dan cardiac output dalam kondisi syok ${ }^{15}$
A. Syok hipovolemik
B. Syok kardiogenik
C. Syok distributif
D. Syok obstruktif

\section{Syok hipovolemik}

Pada kondisi syok hipovolemik (Gambar 6. A), terjadi penurunan volume, ditandai dengan pergeseran kurva venous return dari $\mathrm{A}$ ke $\mathrm{B}$, tubuh berusaha mengkompensasi dengan respon simpatik, sehingga kurva fungsi cardiac bergeser ke kiri. Pemberian cairan akan meningkatkan kurva venous return dari $\mathrm{B}$ ke $\mathrm{C}$, bila dikombinasi dengan kompensasi fungsi cardiac, akan tercapai titik D. ${ }^{9,15}$

\section{Syok kardiogenik}

Pada kondisi syok kardiogenik (Gambar 6. B), terjadi gangguan pada kurva fungsi jantung, kurva bergeser dari A ke B, terjadi karena kontraktilitas jantung yang menurun. Kompensasi tubuh dengan mengeluarkan katekolamin endogen sehingga merubah unstressed volume menjadi stressed volume. MSFP akan meningkat. Peningkatan MSFP juga bisa terjadi karena pemberian cairan. Namun pemberian cairan ini akan meningkatkan total volume tubuh dan stressed volume, tanpa meningkatkan unstressed volume. Dalam kurva akan bergeser dari B ke C. Peningkatan cardiac output yang terjadi tidak bisa maksimal karena adanya disfungsi miokard. Peningkatan yang bermakna bisa terjadi dengan pemberian obat-obat untuk membantu kontraktilitas, misalnya dobutamin dan milrinon. Pemberian obat-obat tersebut 
meningkatkan cardiac output lebih baik, sehingga tercapai cardiac output di titik E. ${ }^{9}$

\section{Syok distributif}

Pada kondisi syok distributif (Gambar 6. C), terjadi hipotensi dengan dilatasi arteriol dan vena. Karakteristik lain yaitu terjadi peningkatan volume dan aliran darah. Sepsis merupakan kondisi syok distributif yang paling sering ditemui pada pasien kritis di ICU. Pada sepsis terjadi aktivasi kaskade inflamasi sebagai respon terhadap infeksi berat. Inflamasi ini memicu dikeluarkannya mediator endogen seperti sitokin, eicosanoid, dan lain sebagainya. Faktorfaktor ini memicu regulasi inducible nitric oxide synthase (NOS) untuk memproduksi nitric oxide, yang merupakan mediator akhir terjadinya relaksasi otot polos pembuluh darah di seluruh sistem kardiovaskular.

Gambar 6. C, menunjukkan fungsi normal cardiac output dan venous return pada titik A. Pada fase awal syok sepsis, terjadi vasodilatasi dan kebocoran vaskular, stressed volume berubah menjadi unstressed volume, total capacitance menurun menyebabkan MSFP menurun. Ini berakibat titik normal A bergeser ke B dimana MSFP menurun namun resistensi masih normal. Pergeseran titik A ke B terjadi pada syok sepsis yang tidak teresusitasi.

Syok sepsis berhubungan dengan dilatasi vena-vena besar dan shunting aliran darah arterial menuju tempat yang lebih rendah resistensinya. Kedua hal tersebut menurunkan resistensi dan menambah venous return. Namun, penurunan resistensi ini ternyata tidak bisa sepenuhnya mengkompensasi penurunan venous return yang disebabkan oleh penurunan MSFP. Pada
Gambar 6. C dapat dilihat perubahan dari B ke C, dimana cardiac output dan venous return sedikit meningkat karena penurunan resistensi.

Pemberian cairan resusitasi pada pasien syok sepsis dapat meningkatkan MSFP. Hal ini mudah dimengerti karena resusitasi cairan meningkatkan stressed volume, namun disisi lain juga dapat menurunkan hemokonsentrasi, menurunkan resistensi. Efek peningkatan MSFP terhadap cardiac output lebih besar dibanding efek pemberian cairan terhadap penurunan resistensi. Pada Gambar 6. C ditunjukkan dengan pergeseran dari titik C ke D.

Pada sebagian besar pasien syok sepsis bila dilakukan pemeriksaan echokardiografi dan radionuclide ventriculografi menunjukkan terjadinya depresi myokard biventrikuler yang bermanifestasi menjadi penurunan ejection fraction (dengan dilatasi kedua ventrikel). Pada Gambar 6. C ditunjukkan pergeseran dari titik D ke E. Pada kasus tertentu, dimana terjadi penurunan kontraktilitas menjadi sangat rendah (titik F), diperlukan penggunaan support obat-obat inotropik. ${ }^{7,15}$

\section{Syok obstruktif}

Pada kasus syok obstruktif (Gambar 6. D), misalnya pada tamponade jantung, tension pneumothoraks atau kompresi vena cava inferior karena abdominal compartement syndrome atau karena kehamilan, dapat menyebabkan penurunan cardiac output karena obstruksi. Tension pneumothoraks menyebabkan penurunan venous return karena adanya peningkatan tekanan intrathoraks. Ini terjadi karena peningkatan tekanan pleura (Ppl) menjadi pembatas venous return, dan bukan lagi tekanan atrium kanan (Pra). 
Persamaan VR=MSFP-CVP berubah menjadi VR=MSFP-Ppl. Venous return tidak lagi bertambah dengan penurunan tekanan atrium kanan. Peningkatan Ppl menyebabkan kurva jantung bergeser ke kanan (titik A bergeser ke B), perbedaan tekanan transmural akan menyempit dan pengisian ventrikel menurun. Titik B bergeser ke $\mathrm{C}$ disebabkan $\mathrm{Ppl}$ yang meningkat akan menyebakan kompresi vena sehingga resistensi vena meningkat. Resistensi yang meningkat akan menurunkan venous return dan cardiac output. Titik C bergeser ke D melalui mekanisme lung colaps dan hipoksemia akut yang terjadi pada tension pneumothoraks, menyebabkan peningkatan PVR. PVR meningkat akan menurunkan venous return. Titik D dapat bergeser ke E apabila diberikan cairan resusitasi yang akan meningkatkan stressed volume dan MSFP sehingga venous return meningkat. Namun hal ini hanya bermanfaat pada pneumothoraks dengan peningkatan Ppl derajat ringan saja. Titik $\mathrm{E}$ akan bergeser ke $\mathrm{F}$ dengan pemberian kombinasi cairan dengan inotropic. Terapi definitif berupa dekompresi masih menjadi terapi utama pada kasus ini. $^{15}$

Pada kasus tamponade jantung, patofisiologinya mirip dengan tension pneumothoraks, hanya saja, VR=MSFPPper dimana Pper adalah tekanan pericardial. Penggunaan cairan dan inotropik hanya untuk kasus tamponade jantung ringan saja, namun terapi utama tetap dekompresi dari tamponade tersebut. $^{7,15}$

\section{RINGKASAN}

Pemahaman mengenai fisiologi cairan dan hubungannya dengan venous return dan cardiac output sangat penting dimiliki oleh klinisi dalam mengelola pasien kritis di ICU. Konsep lama yang melihat sistem kardiovaskular hanya dari konsep jantung kiri saja ternyata tidak bisa menjelaskan banyak hal dalam aplikasi klinis. Seperti dalam tulisan ini, banyak bentuk syok yang melibatkan peran pembuluh darah atau komponen ekstrakardiak lainnya. Gambaran patofisiologi ini memiliki relevansi klinis untuk mengelola pasien dengan patofisiologi penyakit yang kompleks.

\section{DAFTAR PUSTAKA}

1. Bilkovski RN, Rivers EP, Horst HM. Targeted resuscitation strategies after injury. Curr Opin Crit Care.2004;10:529-38

2. Chappnell D, Jacob M, Hofmann K, Conzen P, Rehm M. A rational approach to perioperative management.

Anesthesiology.2008;109:723

3. Bayliss WM, Starling EH. On the same points in the innervation of the mammalian heart. J Physiol. 1992;13:407-18

4. Berlin DA, Bakkker J. Starling curves and central venous pressure. Crit care. 2015;19:55

5. Magder S. Bench to bedside review: An approach to hemodynamic monitoring-Guyton at the bedside. Crit care.2012;16:236

6. Guyton AC, Polizo D, Amstrong GG. Mean circulatory filling pressure measures immediately after cessation of heart pumping. Am J Physiol. 1954;179:261-7

7. Hall JE. Cardiac output, venous return, and their regulation In: Guyton and Hall Textbook of Medical Physiology. $13^{\text {th }}$ ed. Philadelphia: Elsevier;2016.p.245

8. Permutt S, Wice RA. The control of cardiac output through coupling of heart and blood vessel. In: Ventrikular/vascular coupling. New York: Springer; 1987. p.159-79 
9. Magder S. Volume and its relationship to cardiac output and venous return.Crit care.2016;20:271

10. Gelmon S. Venous function and central venous pressure: A physiologic story. Anesthesiology;2008;108:735-48

11. Funk DJ, Jacobsahn E, Kumar A. The role of venous return in critical illness and shock-part 1:Physiology.Crit care med.2013;41(1):255-62

12. Wijnberge $M$, Sindhunata DP, Pinsky MR, Vlaar AP, Ouweneel E, et al. Estimating mean circulatory filling pressure in clinical practice: a systematic review comparing three bedside methods in the critically ill. Ann. Intensive Care;2018:8:73

13. Milnor W. Cardiovascular physiology.New York:Oxford University Press; 1990.

14. Aya HD, Cecconi M. Determinants of venous return in hemodynamic monitoring;2019:4:27-35

15. Funk DJ, Jacobsahn E, Kumar A. The role of venous return in critical illness and shock-part 2: Shock and Mechanical Ventilation. Crit care med.2013; 41(2):573-9 